\title{
Assessment of Different PGPR Formulations as a Biological Fertilizer in Cultivation of Poinsettia (Euphorbia pulcherrima)
}

\author{
Fazilet Parlakova Karagoz", Atilla Dursun \\ Department of Horticulture, Agriculture Faculty, Atatürk University, Erzurum, Turkey \\ Email address: \\ f.parlakova@atauni.edu.tr (F. P. Karagoz) \\ ${ }^{*}$ Corresponding author \\ To cite this article: \\ Fazilet Parlakova Karagoz, Atilla Dursun. Assessment of Different PGPR Formulations as a Biological Fertilizer in Cultivation of Poinsettia \\ (Euphorbia pulcherrima). Frontiers in Environmental Microbiology. Vol. 5, No. 2, 2019, pp. 48-59. doi: 10.11648/j.fem.20190502.12
}

Received: March 13, 2019; Accepted: April 23, 2019; Published: May 20, 2019

\begin{abstract}
Poinsettia (Euphorbia pulcherrima Willd.ex Klotzsch.) is one of the most important potted plants. This research was carried out to determine effects of different PGPR formulations, chemical fertilizers and their combinations on plant growth characteristics and nutrient content of growing medium in two different cultivars (Christmas Feelings and Christmas Eve) of poinsettia. The research was conducted in climate controlled research greenhouse between July 2015 and July 2017. The applications were created as formulation 1 (Paenibacillus polymyxa TV-12E + Pseudomonas putida TV-42A + Pantoea agglomerans RK-79), formulation 2 (Bacillus megaterium TV-91C + Pantoea agglomerans RK-92 + Bacillus subtilis TV17C), formulation 3 (Bacillus megaterium TV-91C + Pantoea agglomerans RK-92 + Kluyvera cryocrescens TV-113C), formulation 4 (Bacillus megaterium TV-91C + Pantoea agglomerans RK-79 + Bacillus megaterium TV-6D), the full amount of commonly used chemical fertilizer $\left(150 \mathrm{~g} \cdot 100 \mathrm{~L}^{-1}\right)(100 \% \mathrm{CF})$ and by combining the reduced amount of chemical fertilizer

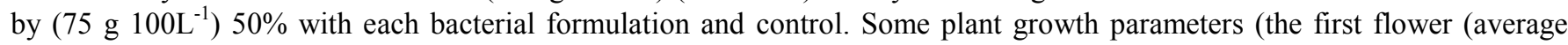
number of days between flowering of the first plant) (day), total growing time up to marketable commercial size (average number of days between time for the forming red colour of $50 \%$ of bracts leaves and the first plant) (day), main flower stalk length $(\mathrm{cm})$ and main flower stalk diameter $(\mathrm{mm})$, total number of leaves (number plant ${ }^{-1}$ ), root collar diameter $(\mathrm{mm})$, fresh weight of plant (g), dry weight of plant (g)) and growing medium characteristics were evaluated in the experiment. In addition to the recommended amount of chemical fertilizer application $(100 \% \mathrm{CF})$ in poinsettia cultivation, BI and BIII bacterial formulation applications were found positive effects on shortening the time until flowering and early flowering. The poinsettia plants grew shortest time marketable commercial size when supplied with BIII+CF application comparing to control. The bacterial viability in the growth medium ranged from $4.91 \times 10^{6} \mathrm{cfu} \mathrm{ml}^{-1}$ to $1.80 \times 10^{7} \mathrm{cfu} \mathrm{ml}^{-1}$. The maximum total nitrogen $(1008.00 \%)$ was obtained from BIV application. The highest solvable phosphorus (12.32 ppm) amount was determined in the $\mathrm{BIV}+\mathrm{CF}$ while the highest potassium $\left(2.02 \mathrm{cmol} \mathrm{kg}^{-1}\right)$ and calcium $\left(8299.03 \mathrm{mg} \mathrm{kg}^{-1}\right)$ amount were found in the BIII application. The poinsettia plants were absorbed sufficient nutrients from the growth medium in $\mathrm{CF}, \mathrm{BI}, \mathrm{BI}+\mathrm{CF}, \mathrm{BII}, \mathrm{BII}+\mathrm{CF}$, BIII, BIII+CF applications and increased in their plant growth and biomass. The bacterial formulations may be used as efficient PGPR for poinsettia production in farmer's greenhouse to reduce the need for chemical fertilizer and improve plant growth.
\end{abstract}

Keywords: Euphorbia pulcherrima Willd.ex Klotzsch., PGPR Formulations, Flowering, Nutrient

\section{Introduction}

Poinsettia (Euphorbia pulcherrima Willd.ex Klotzsch.) or Atatürk çiçeği (Turkish local name) is one of the most important potted plants grown for their flshy bracts and has been used mainly as a traditional Christmas decoration since the $17^{\text {th }}$ century [1]. For Christmas, the main flowers are poinsettias, consumed especially in the colour red traditional version [2]. Greenhouse of poinsettia production is usually programmed for sales in December [3]. In order to make 
poinsettia ready for sale in the Christmas season, the plants are fertilized with each irrigation during the 4-5-month growing period [4-6].

In the production of poinsettia, it is important to produce plants with intensive leaf colour for consumer demand. In order to obtain intense leaf colour, plant nutrition [7] and photoperiod control [8] are known as the most important factors [9]. Inputs or high-performance varieties that provided reduce cost, chemical concentration, fertilizer requirements or facilitated the growth process are attracted great attention of poinsettia producers. There is a growing interest in the ideas of reducing the use of chemicals to protect plant health and reduce production costs. Therefore, the use of bacteria (PGPR) located in the root rhizosphere of plants in agricultural production is increasing in day by day [10-13].

The bacteria, appropriately called rhizobacteria, of the habitat of which is located in a zone surrounding the roots of the plants or rhizosphere are known as plant growth promoting rhizobacteria (PGPR) [10]. PGPR are free-living microorganisms having useful effects on plants fixing $\mathrm{N}$, the synthesis of vitamins and phytohormones, enhanced stress resistance, inhibition of plant ethylene synthesis provided plant nutrient uptake, mineralization of organic phosphate and solubilization of inorganic phosphate [14 -15]. Also, they have used used to prevent or decrease indirectly the detrimental effects of phytopathogens by colonizing in their phyllosphere or rhizosphere [15]. To reduce negative environmental effects by resulting from continuous, use of chemical fertilizers and to improve the physicochemical properties of the growing medium PGPR inoculation may be utilized $[13,14]$. There are few studies on the use of PGPRs in ornamental plant cultivation [16-18]. The number of researches about the use of PGPR [19] in poinsettia production is also very limited in the world.

The objective of this work was to determine the effects of different PGPR formulations, chemical fertilizers and their combinations on plant growth characteristics and nutrient content of growing medium in two different cultivars
(Christmas Feelings and Christmas Eve) of Euphorbia pulcherrima Willd.ex Klotzsch. It was targeted to benefit from these results in cultivation of poinsettia.

\section{Materials and Methods}

\subsection{Experimental Materials and Set-Up}

The research was conducted in climate controlled research greenhouse between July 2015 and July 2017 in Erzurum (Turkey). In the study, rooted cuttings of poinsettia [Euphorbia pulcherrima Willd. ex Klotzsch cv. Christmas Feelings $(\mathrm{CvF})$ and Christmas Eve $(\mathrm{CvE})]$ were used as plant materials. The cultivation medium was prepared by mixing peat in ratio of 2: 1 (diameter: $3,10 \mathrm{~mm}$ ) and pumice (diameter: 10-30 mm) as volume (Lineberger 2018). Plants were planted in 3.5 liter plastic pots.

The applications were created as formulation 1 (Paenibacillus polymyxa TV-12E + Pseudomonas putida TV-42A + Pantoea agglomerans RK-79), formulation 2 (Bacillus megaterium TV-91C + Pantoea agglomerans RK$92+$ Bacillus subtilis TV-17C), formulation 3 (Bacillus megaterium TV-91C + Pantoea agglomerans RK-92 + Kluyvera cryocrescens TV-113C), formulation 4 (Bacillus megaterium TV-91C + Pantoea agglomerans RK-79 + Bacillus megaterium TV-6D) (Table 1), the full amount of

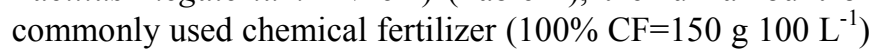
and by combining the reduced amount of chemical fertilizer

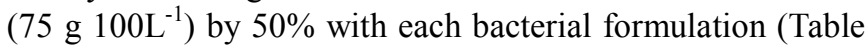
2). The bacterial suspensions (measured spectrophotometrically at $600 \mathrm{~nm}$ ) were properly diluted to $1 \times 10^{8} \mathrm{cfu} \mathrm{m} \mathrm{m}^{-1}$ in $\mathrm{sdH}_{2} \mathrm{O}$. Bacterial formulations were inoculated in the rooted cuttings $(5-8 \mathrm{~cm}$ height $)$ of the poinsettia by dipping method for $15 \mathrm{~min}$ and they were planted in pots filled with appropriate growing medium. The study was designed as 3 replicates in factorial design with 2 (varieties) x 10 (application) (Table 2) in randomized parcel trial design.

Table 1. Bacterial isolates used in the study and some biochemical properties [83].

\begin{tabular}{|c|c|c|c|c|c|c|c|}
\hline Isolate No & MIS Diagnosis Result & SIM & Location (in Turkey) & Host & Nitrogen & Phosphate & Siderophore \\
\hline RK-79 & Pantoea agglomerans & 0.762 & Erzurum & Apple & + & + & - \\
\hline TV-12E & Paenibacillus polymyxa & 0,551 & Van & Poaceae & $\mathrm{S}+$ & + & - \\
\hline TV-17C & Bacillus subtilis & 0.677 & Van & Raspberry & $\mathrm{S}$ & $\mathrm{W}+$ & - \\
\hline TV-6D & Bacillus megaterium & 0.750 & Van & Poaceae & + & + & - \\
\hline TV $-42 \mathrm{~A}$ & Pseudomonas putida & 0.113 & Van & Poaceae & $\mathrm{W}+$ & $\mathrm{W}+$ & + \\
\hline TV-91C & Bacillus megaterium & 0.474 & Van & Poaceae & + & $\mathrm{W}+$ & - \\
\hline TV-113C & Kluyvera cryocrescens & 0.688 & Van & Garlic & + & + & - \\
\hline
\end{tabular}

(SIM: Similarity index, S: Strong +, W: Weak +; +: Positive, -: Negative).

After planting of rooted cuttings (one plant per pot) in pots, two different types of fertilizer in a form that can be completely dissolved in water were applied to the pot groups to be applied chemical fertilizer at the determined different doses. These are comprised from "White 15-0-19+9 $\mathrm{CaO}+$ $2 \mathrm{MgO}+\mathrm{TE}, \mathrm{NPK}$ ratio 4: 0: 5" (white composite fertilizer, granule, containing nitrogen, potassium, calcium, magnesium, boron, zinc, iron, copper, magnesium, molybdenum and manganese) and "Blue 18-11-18 + $2.5 \mathrm{MgO}$, NPK ratio 3: 2: 3" (blue composite fertilizer, granule, containing nitrogen, phosphorus, potassium, sulfur, magnesium, boron, zinc, iron, copper, molybdenum and 
manganese). These two different chemical fertilizers were given in specified amounts with the irrigation water consecutively $[4,20]$. The recommended dose $\left(150 \mathrm{~g} \cdot 100 \mathrm{~L}^{-1}\right)$ of these fertilizers for pots, flowerbeds and all covered seedlings were used in this study.

Table 2. Applications created in the study.

\begin{tabular}{|c|c|}
\hline Code of Application & Applications \\
\hline Control & Control (Uninoculated) \\
\hline $\mathrm{CF}$ & The full amount of commonly used chemical fertilizer $\left(150 \mathrm{~g} \cdot 100 \mathrm{~L}^{-1}\right)(\% 100 \mathrm{CF})$ \\
\hline $\mathrm{BI}$ & Formulation 1 (Paenibacillus polymyxa TV-12E + Pseudomonas putida TV-42A + Pantoea agglomerans $\mathrm{RK}-79)$ \\
\hline BII & Formulation 2 (Bacillus megaterium TV-91C + Pantoea agglomerans RK-92 + Bacillus subtilis TV-17C) \\
\hline BIII & Formulation 3 (Bacillus megaterium TV-91C + Pantoea agglomerans RK-92 + Kluyvera cryocrescens TV-113C) \\
\hline BIV & Formulation 4 (Bacillus megaterium TV-91C + Pantoea agglomerans RK-79 + Bacillus megaterium TV-6D) \\
\hline $\mathrm{BI}+\mathrm{CF}$ & 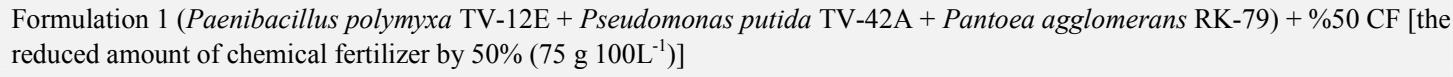 \\
\hline $\mathrm{BII}+\mathrm{CF}$ & 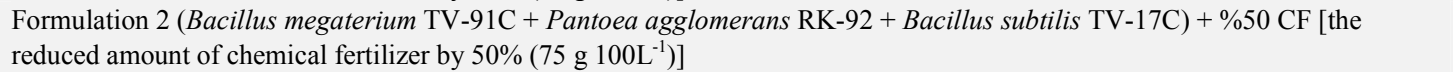 \\
\hline $\mathrm{BIII}+\mathrm{CF}$ & 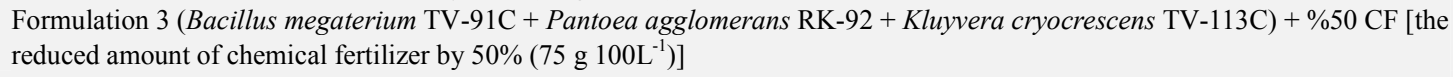 \\
\hline $\mathrm{BIV}+\mathrm{CF}$ & $\begin{array}{l}\text { Formulation } 4 \text { (Bacillus megaterium TV-91C }+ \text { Pantoea agglomerans } \mathrm{RK}-79+\text { Bacillus megaterium } \mathrm{TV}-6 \mathrm{D})+\% 50 \mathrm{CF}[\text { the } \\
\left.\text { reduced amount of chemical fertilizer by } 50 \%\left(75 \mathrm{~g} 100 \mathrm{~L}^{-1}\right)\right]\end{array}$ \\
\hline
\end{tabular}

\subsection{Determinations of Plant Growth Parameters}

After 110-120 days from bacterial inoculation, measurements of some plant growth parameters were made on 10 plants per application. These parameters were the date occurring of the first flower (average number of days between flowering of the first plant) (day), total growing time up to marketable commercial size (average number of days between time for the forming red colour of $50 \%$ of bracts leaves and the first plant) (day), main flower stalk length (cm) and main flower stalk diameter $(\mathrm{mm})$, total number of leaves (number plant ${ }^{-1}$ ), root collar diameter $(\mathrm{mm})$, fresh weight of plant $(\mathrm{g})$, dry weight of plant $(\mathrm{g})$. Diameter was measured to the nearest $0.01 \mathrm{~mm}$ using electronic digital caliper and measuring the root collar diameter (under of the soil line).

\subsection{Measurements of Growth Medium Characteristics}

The growth medium samples (1g each) were taken from the homogenized rhizosphere growth medium fractions of each experimental unit to estimate total number of bacteria, with colony forming units (cfu). The total number of bacteria in growth medium was determined following the method described by Andrade et al. [21]. Taken growing medium samples were separately dried at $27 \pm 2^{\circ} \mathrm{C}$ for $72 \mathrm{~h}$, and passed through a 1-mm sieve. The growing medium $\mathrm{pH}$ was measured on 1:1 extract (Growing medium: Water) [22]. Macronutrients (organic matter (with Smith-Weldon method), P [23], total N (with the Kjeldahl procedure [24]), $\mathrm{K}, \mathrm{Ca}$ and $\mathrm{Mg}$ [25]) and micro contents (Fe, Mn, Zn [26] and $\mathrm{B}$ [27]) of growing medium were also determined. Phosphorus, $\mathrm{K}, \mathrm{Ca}$, and $\mathrm{Mg}$ were determined with an ICP (inductively couples argon plasma) emission spectrometer (Thermo Jarrell Ash Co., Boston, N.Y., USA).

\subsection{Statistical Analysis}

All data in the present study were processed by SPSS (Statistical Package for Social Sciences, Version 22.0) and the means were separated by Duncan's multiple range tests.

\section{Results and Discussion}

\subsection{Plant Parameters}

Days to flowering: In the cultivation of this species, the time of formation of the first flowers in determining the correct planting time is very important as the criterion data. According to the general application averages, the highest mean values with 94.58 day were obtained under the application BIII for days to flowering. The minimum days to flowering was recorded in CF 90.04 day ( $p<0,001$; Figure 1 a). As a result of this research, in addition to the recommended amount of chemical fertilizer application $(100 \% \mathrm{CF})$ in poinsettia cultivation, BI and BIII bacterial formulation applications were found positive effects on shortening the time until flowering and early flowering. Richmond and Radwan [28] stated that the first flowering date can be used in the measurement of the earliness. It was found that there were differences between varieties and the time until flowering for $\mathrm{CvE}$ varieties was shorter. This result can be explained by the genetic characteristics of the varieties [29].

Main flower stalk diameter $(\mathrm{mm})$ : There were no significant differences in main flower stalk diameter among treatments for both years $(p>0.05)$. Significant differences in main flower stalk diameter were found among treatments for varieties $(p<0.001$; Table 3$)$. The main flower stalk diameter of poinsettia ranged from $4.93 \mathrm{~mm}$ to $5.15 \mathrm{~mm}$ and there was not statistically significant in $p<0.05$. In the $\mathrm{CvF}$ variety while the highest value of main flower stalk diameter was determined to be in BII and BI applications with $4.83 \mathrm{~mm}$ and BIII application with $4.81 \mathrm{~mm}$ was in the same statistical group with BI and BII applications $(p<0.01$; Figure 1-b). However, the effect of the all treatments on main flower stalk diameter was not significantly differed $(p>0.05)$. Gurung, et al. [17] documented that the maximum stem thickness was observed in treatment T3 (Azotobacter + PSB $+80 \%$ RDF) 
in Hydrangea as compared to control. Also, Rezvanypour, et al. [30] found that AMF (Arbuscular Mycorrhizal Fungi) inoculation caused significant increase in floral stem diameter for Freesia hybrida plants. The maximum stalk diameter of rose was recorded with Castor cake \# $0.8 \mathrm{~kg}+$ Azotobacter \# $1 \mathrm{ml}+$ PSM \# $1 \mathrm{ml}+\mathrm{KSB}$ \# $1 \mathrm{ml} /$ plant. It might also be due to positively affected by organic manure because chemically, organic manures add an organic compound to the soil. These findings are in conformity with those of [30] in Freesia and [17] in Hydrangea.

Main flower stalk length $(\mathrm{cm})$ : When the general average of the study was evaluated, it was determined that effect of applications $(p<0.001)$ and varieties $(p<0.05)$ on main flower stalk length was statistically significant. The main flower stalk length of poinsettia ranged from $20.08 \mathrm{~cm}$ to $24.96 \mathrm{~cm}$ and showed significantly difference between the treatments. The highest values of main flower stalk length were obtained from $\mathrm{CF}, \mathrm{BI}+\mathrm{CF}$ and $\mathrm{BII}+\mathrm{CF}$ applications. In the $\mathrm{CvE}$ variety, the highest values of main flower stalk length were determined to be in $\mathrm{CF}$ and $\mathrm{BI}+\mathrm{CF}$ applications while
$\mathrm{BII}+\mathrm{CF}$ application was in the same statistical group with $\mathrm{CF}$ and $\mathrm{BI}+\mathrm{CF}$ applications. In the $\mathrm{CvF}$ variety, the highest value of main flower stalk length was determined to be in $\mathrm{BIV}+\mathrm{CF}$ applications and BIV application was in the same statistical group with BIV $+\mathrm{CF}$ application (Table 3). De Silva et al. [31] reported that the application of $P$. fluorescens Pf5 and $B$. pumilus rhizobacteria increased in the length of the main flower stalk of blueberries. Manju and Subramanian [32] demonstrated that the flower stalk length of gerbera was increased in application of liquid formulation of $B$. subtilis strain BG42 and 48.84 per cent increase according to control. This parameter is directly influenced by day length. The main reason for obtaining the longest main flower length in the $\mathrm{CF}$ and $\mathrm{BI}+\mathrm{CF}$ applications of poinsettia varieties grown under the same conditions is estimated to be the addition of nutrients to the growing medium. It is also thought that PGPR accelerate the decomposition of the present and added nutrients and have characteristics of synthesize growthpromoting substances.
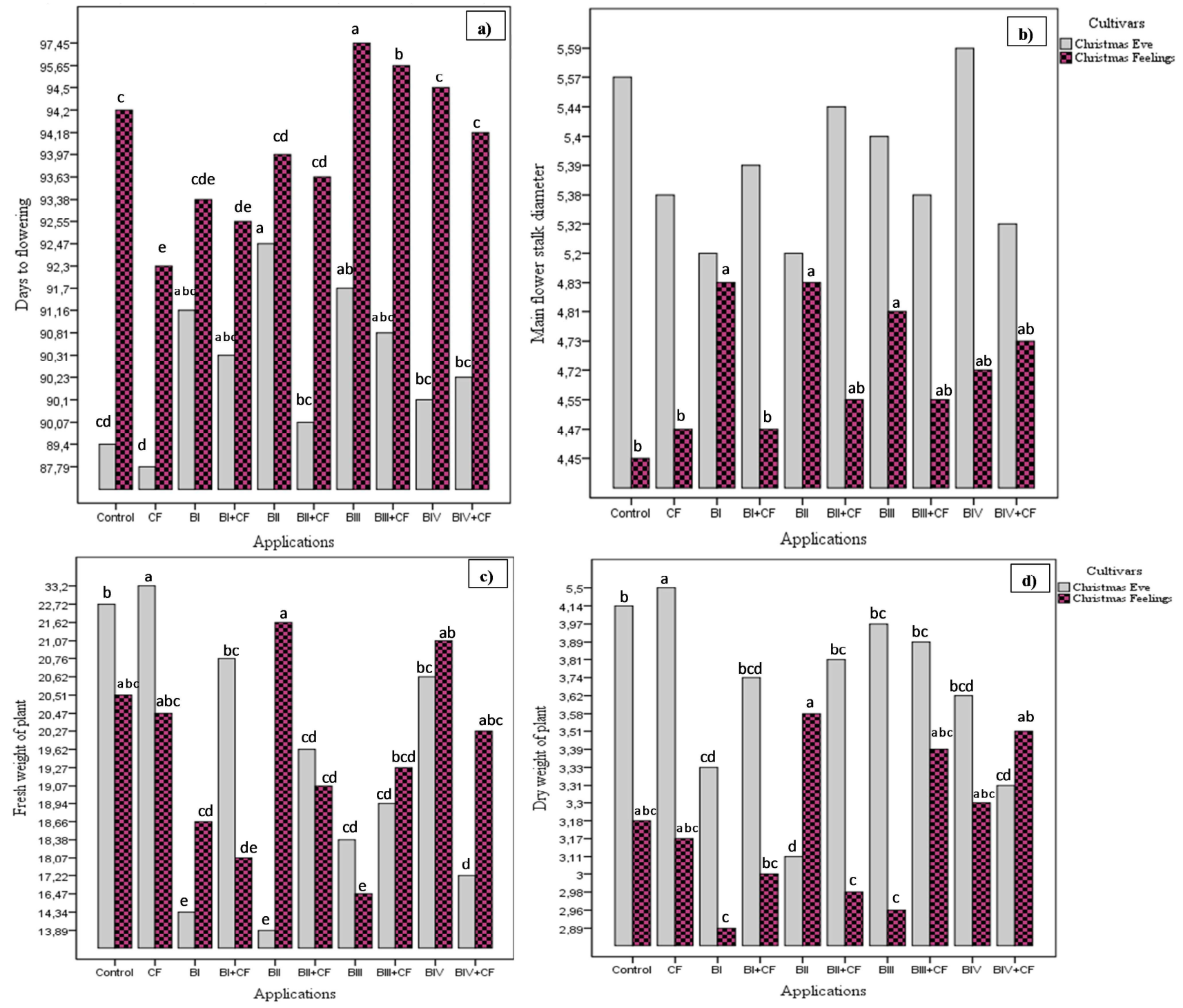

Figure 1. a) Day to flowering (day); b) Main flower stalk diameter (mm); c) Fresh weight of plant (g/plant); d) Dry weight of plant (g/plant). Bars followed by the same letter do not differ from each other according to Duncan's test $(p<0.05)$. 
Total number of leaves (number/plant): The data indicated significant $(p<0.001)$ influence of applications and varieties on total number of leaves of poinsettia. It is vivid from table that the total number of leave (number plant $^{-1}$ ) was recorded with the ranges from 20.86 (BII) to $23.69(\mathrm{BI}+\mathrm{CF})$ and showed significantly difference between the treatments. Significantly maximum total number of leaves was recorded with treatment $\mathrm{BII}+\mathrm{CF}$ for both varieties (Table 3 ). The inoculated PGPRs on Cistus ladanifer flower seedlings increased in the number of leaves, in the study conducted by Solano et al. [33]. Pseudomonas putida rhizobacteria was effective in increasing the number of leaves of poinsettia [19]. It is thought that the reasons for differences determined in terms of the total number of leaves between applications, in previous studies [34-36] and this study may be related to the species and quantity of microorganisms located in the growing medium and that are transformed into the form that the plant can take of the nutrients.

Table 3. Effect of different applications of PGPR and chemical fertilizer on growth of poinsettia.

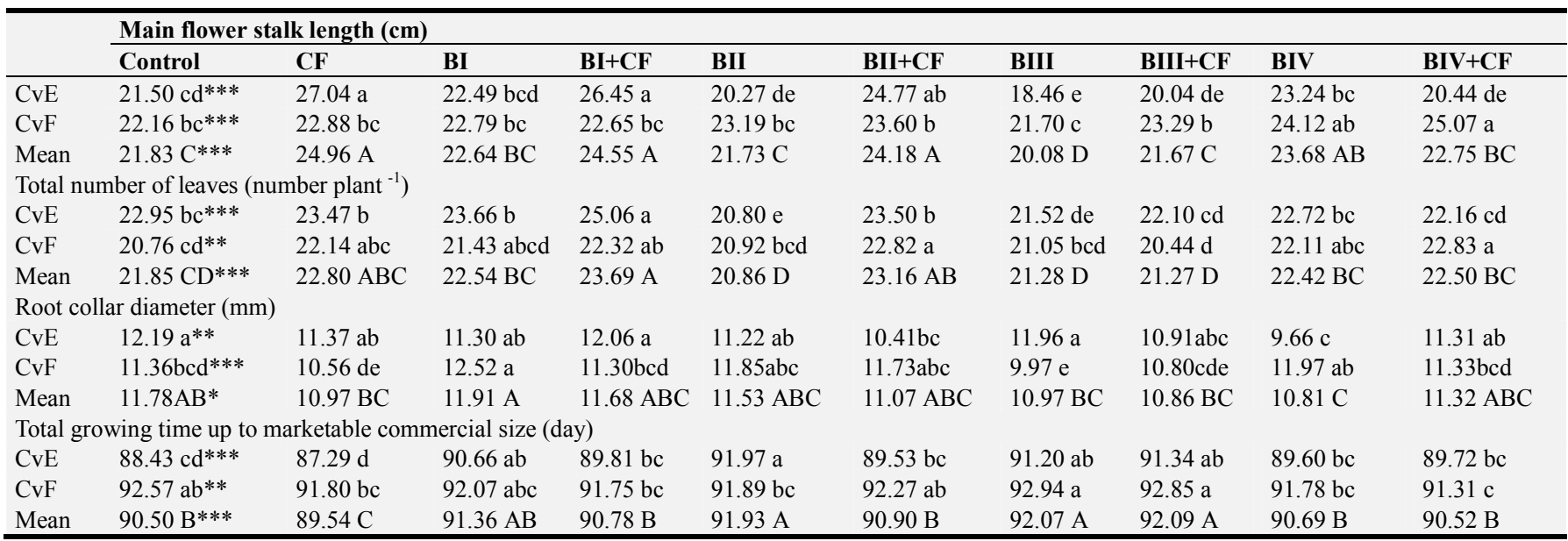

Data points followed by different letters for each parameter are significantly different at $* \mathrm{p}<0.05 ; * * \mathrm{P}<0,01$ and $* * * \mathrm{P}<0,001$ among treatments. Data points followed by ns/NS are not significantly different at $p>0.05$ among treatments. CF:The full amount of commonly used chemical fertilizer $\left.\left.\left(150 \mathrm{~g} \cdot 100 \mathrm{~L}^{-1}\right)\right]\right)(\% 100 \mathrm{CF})$; BI: Paenibacillus polymyxa TV-12E + Pseudomonas putida TV-42A + Pantoea agglomerans RK-79; BII: Bacillus megaterium TV91C + Pantoea agglomerans RK-92 + Bacillus subtilis TV17C; BIII: Bacillus megaterium TV-91C + Pantoea agglomerans RK-92 + Kluyvera cryocrescens TV-113C; BIV: Bacillus megaterium TV-91C + Pantoea agglomerans RK-79 + Bacillus megaterium TV-6D; BI+CF: Paenibacillus polymyxa TV-12E + Pseudomonas putida TV-42A + Pantoea agglomerans RK-79+\%50 CF [the reduced amount of chemical fertilizer by $\left.50 \%\left(75 \mathrm{~g} \cdot 100 \mathrm{~L}^{-1}\right)\right]$; BII $+\mathrm{CF}$ : Bacillus megaterium TV-91C + Pantoea agglomerans RK$92+$ Bacillus subtilis TV-17C $+\% 50 \mathrm{CF}$ [the reduced amount of chemical fertilizer by $\left.50 \%\left(75 \mathrm{~g} \cdot 100 \mathrm{~L}^{-1}\right)\right]$; BIII+CF: Bacillus megaterium TV-91C + Pantoea agglomerans RK-92 + Kluyvera cryocrescens TV-113C $+\% 50 \mathrm{CF}$ [the reduced amount of chemical fertilizer by $50 \%$ $\left.\left(75 \mathrm{~g} \cdot 100 \mathrm{~L}^{-1}\right)\right]$; BIV+CF: Bacillus megaterium TV-91C + Pantoea agglomerans RK-79 + Bacillus megaterium TV-6D $+\% 50 \mathrm{CF}$ [the reduced amount of chemical fertilizer by $50 \%$ (75 g.100L $\left.\mathrm{L}^{-1}\right)$; CvE: Christmas Eve; CvF: Christmas Feelings.

Fresh and dry weight of plant $(g)$ : The study was found that applications factor and variety factor $(p<0.01)$ showed statistically significant in terms of fresh and dry weight of plant. The fresh weight of plant from ranges 16.50 to $26.83 \mathrm{~g}$ and the dry weight of plant ranged from $3.11 \mathrm{~g}$ to $4.33 \mathrm{~g}$. The highest values of fresh and dry weight of plant were obtained from CF application. Eid et al., [37] noted that even plants grown on the fertilization level produced almost higher dry matter produced by plants grown on the chemical fertilizer treatment. The highest values of fresh and dry weight of plant were determined to be in CF (respectively $33.20 \mathrm{~g}$ and 5.50 g) application in the CvE variety and BII (respectively 21.62 $\mathrm{g}$ and $3.58 \mathrm{~g}$ ) application in the $\mathrm{CvF}$ variety (Figure 1c, Figure 1d). Jaleel et al. [38] reported that Pseudomonas fluorescens had positive effects on the fresh and dry weight of the propellant flower (Catharanthus roseus). It was considered the most effective treatment for $\mathrm{CF}$ application in the $\mathrm{CvE}$ variety and $\mathrm{BII}$ application in the CvF variety for increasing in fresh and dry weight/ plant in the present study. The above mentioned results are in harmony with those obtained by Jaleel et al. [38] and Eid et al., [37]. Martinetti et al. [39] reported that the plant weight ranged from 2.03 to $2.85 \mathrm{~g}$. It can be said that dry weight of poinsettia plants increased in the present study when compared the results of study conducted by Martinetti et al. [39].

Root collar diameter $(\mathrm{mm})$ : The results showed that applications factor $(p<0.05)$ was statistically significant, and variety factor $(p>0.05)$ was not statistically significant in terms of root collar diameter of plant. The observation on root collar diameter in poinsettia was presented in Table 3. The data indicated significant influence of, especially, BI treatment on root collar diameter. The root collar diameter (mm) ranged from (BIV application) 10.81 to $11.91 \mathrm{~mm}$ (BI 
application). In our study, the root collar diameter of inoculation with BI (Paenibacillus polymyxa TV-12E + Pseudomonas putida TV-42A + Pantoea agglomerans RK79) was greater than of chemical fertilizer, which was greater than that of control treatments. Won, et al., [40] previously reported that root collar diameter of Pinus thunbergii Parl. was increased in use of Bacillus licheniformis MH48. Also, $\mathrm{Li}$, et al., [41] showed that B. multivorans WS-FJ9 significantly promoted growth in root collar diameter of inoculated poplar seedlings compared with controls. These positive results can be explained by the effects of PGPRs on cell expansion and division [42], improving nutrient uptake, and stimulating growth and development of plant organs [4350].

Total growing time up to marketable commercial size (day): Success in the ornamental plant sector is closely related to the sales time planning required to meet consumer demand and create continuity in the market. When the general averages of the study are examined, it was determined that influence of applications and varieties was statistically significant in terms of total growing time up to marketable commercial size in $p<0.001$ level. The poinsettia plants grew shortest (92.09 day) time marketable commercial size when supplied with BIII+CF application, comparing with other application. BIII+CF application was in the same statistical group with BII and BIII applications. The plants of CvE variety achieved shortest (87.29 day) time marketable commercial size with $\mathrm{CF}$ application. In the CvF variety, the time until the longest up to marketable commercial size was determined to be in BIII and BIII + CF applications while the shortest period was determined in BIV+CF (91.31 day) (Table 3 ). Enhanced yield and marketable grade yield have been reported inoculation of other crops with PGPR in previous studies [51-52]. Eid et al., [37] also, demonstrated that Bacillus and Azotobacter bacterial strains significantly enhanced the early plant growth of Matthiola incana L. plants.

Growth medium parameters

Total number of bacteria in the growth medium (cfu $\mathrm{ml}^{-1}$ ): The study was found that applications factor $(p<0.001)$ was showed statistically significant, and variety factor $(p>0.05)$ was not statistically significant in terms of the total number of bacteria in the growing medium. According to the averages of the values of both years of the experiment, the total number of bacteria in the growing medium ranged from $4.91 \times 10^{6} \mathrm{cfu} \mathrm{ml}^{-1}$ to $1.80 \times 10^{7} \mathrm{cfu} \mathrm{ml}^{-1}$. BIV+CF application resulted in an increase in the number of bacteria by approximately $267 \%$ in the growth medium compared to the control. When the effects of applications for both varieties were separately examined, the maximum number of bacteria in the growth medium was obtained from $\mathrm{BIV}+\mathrm{CF}$ application (Table 4; Figure 2). The total number of colony formation of Azospirillum brasilense and Glomus intraradices was determined as $5.0 \times 10^{6} \mathrm{cfu} \mathrm{g}^{-1}$ in total [53]. Azospirillum brasilense was inoculated into lettuce seeds and bacteria population was determined as $3.1 \times 10^{6} \mathrm{cfu} \mathrm{g}^{-1}, 60$ days after planting [54]. Wheat seed was inoculated with Azospirillum brasilense and 40 days after planting and the total bacterial colony number was determined as $1 \times 10^{12} \mathrm{cfu}$ $\mathrm{g}^{-1}$ [55]. Pérez García et al. [53] interpreted that the total amount of bacterial colonies was affected by the plant species. Accordingly, determining the difference in the number of total bacteria among the varieties in this study can be explained by the literature.
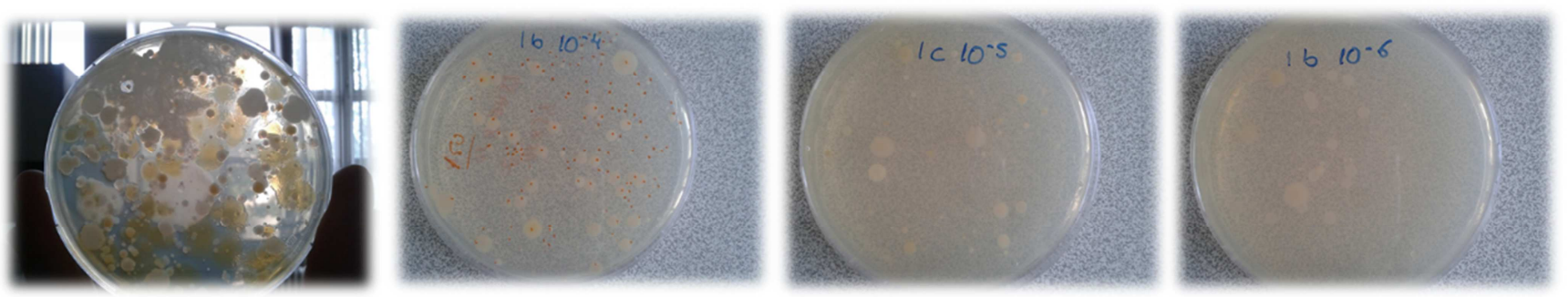

Figure 2. View from the results of total number of bacteria in the growth medium.

Growth medium reaction ( $p H)$ : On analyzing effect of different treatment of chemical fertilizer and PGPR on $\mathrm{pH}$ in the growth medium of poinsettia, it was observed that applications factor $(p<0.001)$ and variety factor $(p<0.01)$ showed statistically significant. According to the average of the data obtained in every two years, the highest $\mathrm{pH}$ value was obtained from control application with 7.53. The highest average $\mathrm{pH}$ value was found in $\mathrm{CvE}$ variety of Poinsettia. The $\mathrm{pH}$ values determined in this study ranged from 7.33 to 7.53 (Table 4). It is said that $\mathrm{pH}$ values of the most suitable growing medium are 5.5-6.5 for the commercial cultivation of poinsettia [6]. It can be said that the $\mathrm{pH}$ levels determined in the present study can be tolerated by different varieties of poinsettia and that more than 6.5 of these values do not lead to major problems in cultivation of these varieties.
Organic matter (\%): At the end of the experiment, the study was found that applications factor and variety factor $(p<0.001)$ showed statistically significant in terms of organic matter of the growth medium. In the present study, the highest organic matter value was obtained from BIV application; the rate of organic matter in samples of the growth medium was found between $1.67 \%$ and $1.91 \%$ according to the general average of the applications. The highest organic matter was obtained from BIV application in every two poinsettia cultivar. The lowest organic matter was obtained from the control application in the $\mathrm{CvE}$ cultivar and it was determined in control and CF applications in the CvF cultivar (Table 4). The organic matter content of the growing medium in the cultivation of potted poinsettia is very important. Reasons for the increasing in percentage of organic matter of the BIV bacteria formulation in this study may be 
nutrients containing more decomposed by bacteria and that these bacteria have more activities and numbers [56]. Prasad [57], Cakmakçi et al. [58] and Chen [59] said that bacteria decompose the nutrients connected in organic matter and thus they have played a very important role in making the plant available. Explanation of the results of this study and previous studies are possible to do with other studies $[60,45,61-62,58]$ that stated improvement of plant nutrient uptake, increasing in plant growth through phytohormone and vitamin synthesis.

Total nitrogen (\%): The data indicated significant $(p<0.001)$ influence of applications and varieties on total nitrogen in the growth medium of poinsettia. In the present study, the highest total nitrogen was obtained from BIV application, according to the general average of the applications. BIV application increased in the total nitrogen by approximately $12.75 \%$ in the growth medium when compared to the control (Table 4). Orhan et al. [63] and Singh and Chauhan [64] reported that bacterial applications affect on the total nitrogen content of the growth medium. PGPRs are known to play an active role in ensuring that plants receive better nutrients and in ensuring that plant growth, development and quality with hormonal activity and suppressing harmful microorganisms naturally found in the plant root [62]. It was stated that PGPR strains such as Azoarcus sp., Klebsiella pneumoniae, Beijerinckia sp., Rhizobium sp. and
Pantoea agglomerans stabilize atmospheric $\mathrm{N}_{2}$ in the soil [65] and make them available to the plant [66]. In this study, taking place of Pantoea agglomerans bacteria strain in the bacterial formulation in which the highest total nitrogen was obtained, was found to be compatible with the previous study results.

Available phosphorus (ppm): The data explained significantly $(p<0.001)$ difference between applications and varieties on available phosphorus in the growth medium of poinsettia. When the averages of the two years of study and both varieties of poinsettia were examined and the highest amount of phosphorus was obtained from BIV+CF application with $12.32 \mathrm{ppm}$, and the lowest amount of phosphorus with 9.44 ppm was obtained from the control application (Table 4). The soil samples of all PGPR combined fertilizer applications in the study done by Das and Singh [67] were contained higher N, P and K than the fertilizer applications without PGPR. In addition, Singh and Subba Rao [68], Prasad and Chandra [69] and Gunasekaran et al. [70] found that Bacillus megaterium increases in the available $\mathrm{P}$ content of soil. As a result of the study conducted by Arab et al. [71], depending on the activity of Pseudomonas bacteria, accessing to the nitrogen and phosphorus elements in the soil was increased. The fact that PGPRs can quickly dissolve the phosphates used by the plants promotes in plant growth [72].

Table 4. Effect of the treatments on total number of bacteria in the growth medium, $\mathrm{pH}$, organic matter, total $\mathrm{N}, \mathrm{P}, \mathrm{K}$, Ca and Mg at different treatment growth medium of Euphorbia pulcherrima Willd.ex Klotzsch.

\begin{tabular}{|c|c|c|c|c|c|c|c|c|c|c|}
\hline \multicolumn{11}{|c|}{ Total number of bacteria in the growth medium $\left(\times 10^{6} \mathrm{cfu} \mathrm{ml}^{-1}\right)$} \\
\hline & Control & CF & BI & $\mathrm{BI}+\mathrm{CF}$ & BII & $\mathrm{BII}+\mathrm{CF}$ & BIII & $\mathrm{BIII}+\mathrm{CF}$ & BIV & $\mathrm{BIV}+\mathrm{CF}$ \\
\hline $\mathrm{CvE}$ & $5.62 \mathrm{~g} * * *$ & 9.18 ef & 9.15 ef & $10.07 \mathrm{de}$ & $7.93 \mathrm{f}$ & $11.07 \mathrm{~d}$ & $8.05 \mathrm{f}$ & $13.10 \mathrm{c}$ & $15.75 \mathrm{~b}$ & $17.37 \mathrm{a}$ \\
\hline $\mathrm{CvF}$ & $4.20 \mathrm{~g} * * *$ & $11.78 \mathrm{c}$ & $9.85 \mathrm{~d}$ & $14.92 \mathrm{~b}$ & $7.87 \mathrm{e}$ & $14.45 \mathrm{~b}$ & $6.37 \mathrm{f}$ & $6.95 \mathrm{ef}$ & $12.18 \mathrm{c}$ & $18.68 \mathrm{a}$ \\
\hline $\begin{array}{l}\text { Mean } \\
\mathrm{pH}\end{array}$ & $4.91 \mathrm{G}^{* * *}$ & $10.48 \mathrm{D}$ & $9.50 \mathrm{E}$ & $12.49 \mathrm{C}$ & $7.90 \mathrm{~F}$ & $12.76 \mathrm{C}$ & $7.21 \mathrm{~F}$ & $10.03 \mathrm{DE}$ & $13.97 \mathrm{~B}$ & $18.03 \mathrm{~A}$ \\
\hline $\mathrm{CvE}$ & $7.60 \mathrm{a}^{* * *}$ & $7.31 \mathrm{e}$ & $7.27 \mathrm{f}$ & $7.53 \mathrm{~b}$ & $7.44 \mathrm{~d}$ & $7.47 \mathrm{~cd}$ & $7.50 \mathrm{bc}$ & $7.47 \mathrm{~cd}$ & $7.21 \mathrm{~g}$ & $7.29 \mathrm{ef}$ \\
\hline $\mathrm{CvF}$ & $7.47 \mathrm{a}^{* * *}$ & $7.44 \mathrm{a}$ & $7.39 \mathrm{~b}$ & $7.46 \mathrm{a}$ & $7.33 \mathrm{c}$ & $7.38 \mathrm{~b}$ & $7.29 \mathrm{~d}$ & $7.33 \mathrm{c}$ & $7.39 \mathrm{~b}$ & $7.45 \mathrm{a}$ \\
\hline Mean & $7.53 \mathrm{~A}^{* * *}$ & $7.37 \mathrm{EF}$ & $7.33 \mathrm{G}$ & $7.49 \mathrm{~B}$ & 7.38 DEF & $7.42 \mathrm{C}$ & $7.39 \mathrm{DE}$ & $7.40 \mathrm{D}$ & $7.30 \mathrm{H}$ & $7.37 \mathrm{~F}$ \\
\hline \multicolumn{11}{|c|}{ Organic Mater (\%) } \\
\hline $\mathrm{CvE}$ & $1.82 \mathrm{e}^{* * *}$ & $1.78 \mathrm{de}$ & $1.90 \mathrm{bcd}$ & $1.98 \mathrm{ab}$ & $1.89 \mathrm{~cd}$ & $1.96 \mathrm{abc}$ & $1.95 \mathrm{abc}$ & $1.83 \mathrm{de}$ & $2.01 \mathrm{a}$ & $1.85 \mathrm{de}$ \\
\hline $\mathrm{CvF}$ & $1.60 \mathrm{c}^{* * *}$ & $1.56 \mathrm{c}$ & $1.70 \mathrm{~b}$ & $1.70 \mathrm{~b}$ & $1.66 \mathrm{~b}$ & $1.66 \mathrm{~b}$ & $1.69 \mathrm{~b}$ & $1.68 \mathrm{~b}$ & $1.82 \mathrm{a}$ & $1.72 \mathrm{~b}$ \\
\hline Mean & $1.71 \mathrm{EF}^{* * *}$ & $1.67 \mathrm{~F}$ & $1.80 \mathrm{BCD}$ & $1.84 \mathrm{~B}$ & $1.77 \mathrm{CD}$ & $1.81 \mathrm{BC}$ & $1.82 \mathrm{BC}$ & $1.76 \mathrm{DE}$ & $1.91 \mathrm{~A}$ & $1.78 \mathrm{CD}$ \\
\hline \multicolumn{11}{|c|}{ Total Nitrogen $(\%)$} \\
\hline $\mathrm{CvE}$ & $0.0938 \mathrm{f}^{* * *}$ & 0.0913 ef & 0.0978 bcde & $0.1020 \mathrm{ab}$ & 0.0968 cde & $\begin{array}{l}0.1010 \\
\text { abc }\end{array}$ & $0.1003 \mathrm{abcd}$ & 0.0942 ef & $0.1033 \mathrm{a}$ & $\begin{array}{l}0.0953 \\
\text { def }\end{array}$ \\
\hline $\mathrm{CvF}$ & $0.0850 \mathrm{c} * * *$ & $0.0850 \mathrm{c}$ & $0.0900 \mathrm{bc}$ & $0.0900 \mathrm{bc}$ & $0.0883 \mathrm{bc}$ & $0.0883 \mathrm{bc}$ & $0.0917 \mathrm{~b}$ & $0.0917 \mathrm{~b}$ & $0.0983 \mathrm{a}$ & $0.0933 \mathrm{~b}$ \\
\hline Mean & $0.0894 \mathrm{CD}^{* * *}$ & $0.0882 \mathrm{D}$ & $0.0939 \mathrm{~B}$ & $0.0960 \mathrm{~B}$ & $0.0926 \mathrm{BC}$ & $0.0947 \mathrm{~B}$ & $0.0960 \mathrm{~B}$ & $0.0929 \mathrm{~B}$ & $0.1008 \mathrm{~A}$ & $0.0943 \mathrm{~B}$ \\
\hline \multicolumn{11}{|c|}{$\mathrm{P}(\mathrm{ppm})$} \\
\hline $\mathrm{CvE}$ & $9.54 \mathrm{~d}^{* * *}$ & $10.05 \mathrm{~d}$ & $11.35 \mathrm{c}$ & $10.07 \mathrm{~d}$ & $11.06 \mathrm{c}$ & $10.27 \mathrm{~d}$ & $12.17 \mathrm{ab}$ & $11.53 \mathrm{bc}$ & $11.17 \mathrm{c}$ & $12.62 \mathrm{a}$ \\
\hline $\mathrm{CvF}$ & $9.04 \mathrm{e}^{* * *}$ & $9.20 \mathrm{e}$ & $10.15 \mathrm{~d}$ & $9.88 \mathrm{~d}$ & $10.75 \mathrm{bc}$ & $9.95 \mathrm{~d}$ & $11.16 \mathrm{~b}$ & $11.04 \mathrm{~b}$ & $10.43 \mathrm{~cd}$ & $11.92 \mathrm{a}$ \\
\hline Mean & $9.29 \mathrm{G}^{* * *}$ & $9.63 \mathrm{FG}$ & $10.75 \mathrm{D}$ & $9.98 \mathrm{EF}$ & $10.90 \mathrm{CD}$ & $10.11 \mathrm{E}$ & $11.67 \mathrm{~B}$ & $11.29 \mathrm{BC}$ & $10.80 \mathrm{D}$ & $12.27 \mathrm{~A}$ \\
\hline \multicolumn{11}{|c|}{$\mathrm{K}\left(\mathrm{cmol} \mathrm{kg}^{-1}\right)$} \\
\hline $\mathrm{CvE}$ & $2.07 \mathrm{~cd}^{* * *}$ & $1.93 \mathrm{e}$ & $2.08 \mathrm{~cd}$ & $2.15 \mathrm{abc}$ & $2.14 \mathrm{bcd}$ & $2.07 \mathrm{~cd}$ & $2.22 \mathrm{ab}$ & $2.26 \mathrm{a}$ & $2.01 \mathrm{de}$ & $2.08 \mathrm{~cd}$ \\
\hline $\mathrm{CvF}$ & $1.71 \mathrm{~cd}^{* * *}$ & $1.61 \mathrm{e}$ & $1.74 \mathrm{bc}$ & $1.79 \mathrm{ab}$ & $1.78 \mathrm{ab}$ & $1.67 \mathrm{~d}$ & $1.82 \mathrm{a}$ & $1.76 \mathrm{bc}$ & $1.79 \mathrm{ab}$ & $1.82 \mathrm{a}$ \\
\hline Mean & $1.89 \mathrm{DE}^{* * *}$ & $1.77 \mathrm{~F}$ & $1.91 \mathrm{CDE}$ & $1.97 \mathrm{ABC}$ & $1.96 \mathrm{ABCD}$ & $1.87 \mathrm{E}$ & $2.02 \mathrm{~A}$ & $2.01 \mathrm{AB}$ & $1.90 \mathrm{CDE}$ & $1.95 \mathrm{BCD}$ \\
\hline \multicolumn{11}{|c|}{$\mathrm{Ca}\left(\mathrm{cmol} \mathrm{kg}^{-1}\right)$} \\
\hline $\mathrm{CvE}$ & $12.67 \mathrm{c}^{* * *}$ & $13.71 \mathrm{~b}$ & $14.76 \mathrm{a}$ & $13.32 \mathrm{bc}$ & $14.01 \mathrm{~b}$ & $13.27 \mathrm{bc}$ & $15.32 \mathrm{a}$ & $13.94 \mathrm{~b}$ & $14.97 \mathrm{a}$ & $13.97 \mathrm{~b}$ \\
\hline $\mathrm{CvF}$ & $14.48 \mathrm{~cd}^{* * *}$ & $14.04 \mathrm{~d}$ & $15.23 \mathrm{~b}$ & $14.45 \mathrm{~cd}$ & $15.08 \mathrm{~b}$ & $14.63 \mathrm{c}$ & $16.11 \mathrm{a}$ & $14.32 \mathrm{~cd}$ & $15.14 \mathrm{~b}$ & $14.02 \mathrm{~d}$ \\
\hline Mean & $13.58 \mathrm{E}^{* * *}$ & $13.88 \mathrm{DE}$ & $14.99 \mathrm{~B}$ & $13.89 \mathrm{DE}$ & $14.54 \mathrm{C}$ & $13.95 \mathrm{DE}$ & $15.71 \mathrm{~A}$ & 14.13 DE & $15.05 \mathrm{~B}$ & $14.00 \mathrm{D}$ \\
\hline \multicolumn{11}{|c|}{$\operatorname{Mg}\left(\mathrm{cmol} \mathrm{kg}^{-1}\right)$} \\
\hline $\mathrm{CvE}$ & $2.25 \mathrm{c} * * *$ & $2.24 \mathrm{c}$ & $2.36 \mathrm{~b}$ & $2.22 \mathrm{c}$ & $2.43 \mathrm{~b}$ & $2.36 \mathrm{~b}$ & $2.39 \mathrm{~b}$ & $2.35 \mathrm{~b}$ & $2.53 \mathrm{a}$ & $2.23 \mathrm{c}$ \\
\hline $\mathrm{CvF}$ & $2.07 \mathrm{f} * * *$ & $2.05 \mathrm{f}$ & $2.28 \mathrm{~cd}$ & $2.18 \mathrm{e}$ & $2.38 \mathrm{~b}$ & $2.23 \mathrm{~d}$ & $2.50 \mathrm{a}$ & $2.38 \mathrm{~b}$ & $2.34 \mathrm{bc}$ & $2.15 \mathrm{e}$ \\
\hline Mean & $2.16 \mathrm{E}^{* * *}$ & $2.14 \mathrm{E}$ & $2.32 \mathrm{CD}$ & $2.20 \mathrm{E}$ & $2.41 \mathrm{AB}$ & $2.30 \mathrm{D}$ & $2.45 \mathrm{~A}$ & $2.36 \mathrm{BC}$ & $2.43 \mathrm{~A}$ & $2.19 \mathrm{E}$ \\
\hline
\end{tabular}

Available potassium $\left(\mathrm{cmol} \mathrm{kg}^{-1}\right)$ : The data indicated significant $(p<0.001)$ influence of applications and varieties 
on available potassium in the growth medium of poinsettia. The highest amount of available potassium was obtained from BIII application with $2.02 \mathrm{cmol} \mathrm{kg}^{-1}$ and the lowest amount of available potassium with $1.77 \mathrm{cmol} \mathrm{kg}^{-1}$ was obtained from the CF application. The highest potassium was obtained from the BIII+CF application in the CvE cultivar while it was determined in BIII and $\mathrm{BIV}+\mathrm{CF}$ applications in the $\mathrm{CvF}$ cultivar. The lowest potassium was obtained from the CF for every two varieties (Table 4). In the present study, the amount of available potassium was increased in the growth medium by using PGPR applications. This increase may be due to the production of carboxylic acids such as citric, tartaric and oxalic acid [73-75].

Available calcium $\left(\mathrm{cmol} \mathrm{kg}^{-1}\right)$ : The data indicated significant $(p<0.001)$ influence of applications and varieties on available calcium in the growth medium of poinsettia. It was reported that poinsettia requires high levels of nitrogen and potassium [76], and also a high percentage of calcium, magnesium and molybdenum are needed [77]. In the present study, the highest amount of available calcium was obtained from BIII application, according to the general average of the applications. The lowest amount of available calcium was obtained from the control and BI applications. The highest calcium was obtained from the BI, BIII and BIV applications in the CvE cultivar while it was determined in BIII application in the CvF cultivar (Table 4). According to McAvoy and Bible [78], the nutrition of calcium (Ca), molybdenum (Mo) and boron (B) is critical to produce quality poinsettia. During this study, no signs of deficiency were observed in the poinsettia plants. As can be seen from the results, the calcium nutrition needed by the plant was sufficient in the present study.

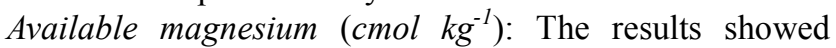
significant $(p<0.001)$ influence of applications and varieties on available magnesium in the growth medium of poinsettia.
When the averages of the two years of study were examined; the highest amount of available magnesium was obtained from BIII and BIV applications. The highest magnesium was obtained from the BIV application in the CvE cultivar and it was determined in BIII application in the $\mathrm{CvF}$ cultivar (Table 4). In the research, the bacterial formulations were increased in the amount of available magnesium. Reason of this increase may be due to the role of PGPRs in the synthesis of growth hormones such as auxin and other mechanism properties [60-62, 58].

Available iron $\left(\mathrm{mg} \mathrm{kg}^{-1}\right)$ : Overall, there were significant differences among $(p<0.001)$ applications and varieties factors on available $\mathrm{Fe}$ in the growth medium of poinsettia. According to the averages of the two years of study, the highest amount of available iron was obtained from BIV applications as $3.22 \mathrm{mg} \mathrm{kg}^{-1}$. The highest iron was obtained from the BIV application in the CvE cultivar while it was determined in BIII application in the CvF cultivar according to control application (Table 5). Rhizosphere bacteria, by releasing siderophore compounds, increase in their competitive potential by preventing the growth of other microorganisms, pathogens, and limiting existing iron. They improve the nutrition of the plant directly and indirectly [7980].

Available manganese ( $m g \mathrm{~kg}^{-1}$ ): The data indicated significant $(p<0.001)$ influence of applications and varieties on available $\mathrm{Mn}$ in the growth medium of poinsettia. In the present study, the highest amount of available manganese was obtained from BIV application as $5.06 \mathrm{mg} \mathrm{kg}^{-1}$ according to the general average of the applications (Table 5). Manganese is taken up by plants from the soil very quickly. It does not bind to insoluble organic ligands or root tissues. In addition, the toxicity of $\mathrm{Mn}$ varies according to the plant factors [81]. In this study, no deficiencies or toxic effects related to $\mathrm{Mn}$ were observed in poinsettia varieties.

Table 5. Effect of the treatments on Fe, Mn, Zn and B at different treatment growth medium of Euphorbia pulcherrima Willd.ex Klotzsch.

\begin{tabular}{|c|c|c|c|c|c|c|c|c|c|c|}
\hline & \multicolumn{10}{|l|}{$\mathrm{Fe}\left(\mathrm{mg} \mathrm{kg}^{-1}\right)$} \\
\hline & Control & $\mathrm{CF}$ & BI & $\mathrm{BI}+\mathrm{CF}$ & BII & $\mathrm{BII}+\mathrm{CF}$ & BIII & BIII+CF & BIV & $\mathrm{BIV}+\mathrm{CF}$ \\
\hline $\mathrm{CvE}$ & $2.76 \mathrm{e}^{* * *}$ & $3.23 \mathrm{~d}$ & $3.65 \mathrm{ab}$ & $3.38 \mathrm{~cd}$ & $3.58 \mathrm{abc}$ & $3.30 \mathrm{~d}$ & $3.60 \mathrm{abc}$ & $3.22 \mathrm{~d}$ & $3.77 \mathrm{a}$ & $3.44 \mathrm{bcd}$ \\
\hline $\mathrm{CvF}$ & $1.91 \mathrm{~g} * * *$ & $2.26 \mathrm{f}$ & $2.53 \mathrm{~cd}$ & $2.45 \mathrm{de}$ & $2.63 \mathrm{bc}$ & $2.42 \mathrm{e}$ & $2.80 \mathrm{a}$ & $2.41 \mathrm{e}$ & $2.67 \mathrm{~b}$ & $2.45 \mathrm{de}$ \\
\hline Mean & $2.33 \mathrm{~F}^{* * *}$ & $2.74 \mathrm{E}$ & $3.09 \mathrm{~B}$ & $2.92 \mathrm{CD}$ & $3.10 \mathrm{AB}$ & $2.86 \mathrm{CDE}$ & $3.20 \mathrm{AB}$ & $2.81 \mathrm{DE}$ & $3.22 \mathrm{~A}$ & $2.94 \mathrm{C}$ \\
\hline \multicolumn{11}{|c|}{$\operatorname{Mn}\left(\mathrm{mg} \mathrm{kg}^{-1}\right)$} \\
\hline $\mathrm{CvE}$ & $4.17 \mathrm{e}^{* * *}$ & $5.32 \mathrm{ab}$ & $5.68 \mathrm{a}$ & $4.93 \mathrm{bc}$ & $4.98 \mathrm{bc}$ & $4.93 \mathrm{bc}$ & $4.66 \mathrm{~cd}$ & $4.29 \mathrm{de}$ & $5.68 \mathrm{a}$ & $5.14 \mathrm{~b}$ \\
\hline $\mathrm{CvF}$ & $3.64 \mathrm{de}^{* * *}$ & $3.98 \mathrm{bcd}$ & $4.08 \mathrm{abc}$ & 3.91 bcde & $4.13 \mathrm{ab}$ & 3.92 bcde & $4.21 \mathrm{ab}$ & $3.58 \mathrm{e}$ & $4.44 \mathrm{a}$ & 3.73 cde \\
\hline Mean & $3.90 \mathrm{D}^{* * *}$ & $4.65 \mathrm{BC}$ & $4.88 \mathrm{AB}$ & $4.42 \mathrm{C}$ & $4.55 \mathrm{C}$ & $4.43 \mathrm{C}$ & $4.43 \mathrm{C}$ & $3.93 \mathrm{D}$ & $5.06 \mathrm{~A}$ & $4.43 \mathrm{C}$ \\
\hline \multicolumn{11}{|c|}{$\mathrm{Zn}\left(\mathrm{mg} \mathrm{kg}^{-1}\right)$} \\
\hline $\mathrm{CvE}$ & $1.79 \mathrm{~g} * * *$ & $2.57 \mathrm{de}$ & $3.20 \mathrm{~b}$ & $2.49 \mathrm{de}$ & $2.62 \mathrm{de}$ & $2.26 \mathrm{f}$ & $2.66 \mathrm{~d}$ & $2.42 \mathrm{ef}$ & $3.46 \mathrm{a}$ & $2.98 \mathrm{c}$ \\
\hline $\mathrm{CvF}$ & $1.25 \mathrm{~d}^{* * *}$ & $1.36 \mathrm{~cd}$ & $1.68 \mathrm{ab}$ & $1.53 \mathrm{bcd}$ & $1.49 \mathrm{bcd}$ & $1.45 \mathrm{bc}$ & $1.88 \mathrm{a}$ & $1.56 \mathrm{bcd}$ & $1.87 \mathrm{a}$ & $1.52 \mathrm{bcd}$ \\
\hline Mean & $1.52 \mathrm{~F}^{* * *}$ & $1.97 \mathrm{DE}$ & $2.44 \mathrm{~B}$ & $2.01 \mathrm{DE}$ & $2.05 \mathrm{D}$ & $1.86 \mathrm{E}$ & $2.27 \mathrm{C}$ & $1.99 \mathrm{DE}$ & $2.66 \mathrm{~A}$ & $2.25 \mathrm{C}$ \\
\hline \multicolumn{11}{|c|}{$\mathrm{B}\left(\mathrm{mg} \mathrm{kg}^{-1}\right)$} \\
\hline $\mathrm{CvE}$ & $0.47 \mathrm{~d}^{* * *}$ & $0.46 \mathrm{~d}$ & $0.53 \mathrm{~d}$ & $0.50 \mathrm{~d}$ & $0.61 \mathrm{c}$ & $0.64 \mathrm{c}$ & $0.72 \mathrm{~b}$ & $0.86 \mathrm{a}$ & $0.73 \mathrm{~b}$ & $0.71 \mathrm{~b}$ \\
\hline $\mathrm{CvF}$ & $0.35 \mathrm{~d}^{* * *}$ & $0.39 \mathrm{~d}$ & $0.48 \mathrm{bc}$ & $0.45 \mathrm{c}$ & $0.50 \mathrm{bc}$ & $0.49 \mathrm{bc}$ & $0.52 \mathrm{~b}$ & $0.52 \mathrm{~b}$ & $0.62 \mathrm{a}$ & $0.61 \mathrm{a}$ \\
\hline Mean & $0.41 \mathrm{E}^{* * *}$ & $0.43 \mathrm{E}$ & $0.51 \mathrm{D}$ & $0.47 \mathrm{D}$ & $0.55 \mathrm{C}$ & $0.57 \mathrm{C}$ & $0.62 \mathrm{~B}$ & $0.69 \mathrm{~A}$ & $0.67 \mathrm{~A}$ & $0.66 \mathrm{AB}$ \\
\hline
\end{tabular}

Available zinc $\left(m g \quad \mathrm{~kg}^{-1}\right)$ : The differences among applications and cultivars were statistically significant $(p<0.001)$ in terms of available zinc in the growth medium of poinsettia. When the averages of the two years of study were examined; the amount of available zinc ranged from $1.52 \mathrm{mg}$ $\mathrm{kg}^{-1}$ to $2.66 \mathrm{mg} \mathrm{kg}^{-1}$. While the highest amount of available zinc was obtained from BIV application, the lowest amount of available zinc was found in control application. The highest zinc was obtained from the BIV application in the $\mathrm{CvE}$ cultivar and it was determined in BIII and BIV 
applications in the $\mathrm{CvF}$ cultivar according to control application (Table 5). In the present study, the amount of chemical fertilizer applied for intensive leaf colour production can be reduced by the use of BIV bacterial formulation and the highest amount of zinc was determined in the same application. The results of this study were consistent with the results of the study by Balashouri [82].

Available boron $\left(\mathrm{mg} \mathrm{kg}^{-1}\right)$ : The results indicated significant $(p<0.001)$ influence of applications and varieties factors on available $B$ in the growth medium of poinsettia. While the highest amount of available boron was obtained from BIII+CF (0.69 $\left.\mathrm{mg} \mathrm{kg}^{-1}\right)$ and BIV $\left(0.67 \mathrm{mg} \mathrm{kg}^{-1}\right)$ applications, the lowest amount of available zinc was found in control (0.41 $\left.\mathrm{mg} \mathrm{kg}^{-1}\right)$ and $\mathrm{CF}\left(0.43 \mathrm{mg} \mathrm{kg}^{-1}\right)$ applications (Table 5). Micro elements such as $\mathrm{Ca}$, Mo and B play an important role in the growth of poinsettia [7]. In this study, no deficiencies or toxic effects related to $\mathrm{B}$ were observed in poinsettia varieties.

\section{Conclusions}

BI and BIII bacterial formulation applications as well as the recommended amount of chemical fertilizer application $(100 \% \mathrm{CF})$ in poinsettia cultivation were found positive effects on shortening the time until flowering and early flowering. The poinsettia plants grew shortest time marketable commercial size when supplied with BIII+CF application. The poinsettia plants were absorbed sufficient nutrients from the growth medium in $\mathrm{CF}, \mathrm{BI}, \mathrm{BI}+\mathrm{CF}, \mathrm{BII}$, $\mathrm{BII}+\mathrm{CF}, \mathrm{BIII}, \mathrm{BIII}+\mathrm{CF}$ applications and increased in their plant growth and biomass. In contrast, maximum plant nutrients in the growth medium samples have especially determined in the BIV application. The present study showed that $\mathrm{BI}, \mathrm{BI}+\mathrm{CF}, \mathrm{BII}, \mathrm{BII}+\mathrm{CF}, \mathrm{BIII}, \mathrm{BIII}+\mathrm{CF}$ applications as an alternative to $\mathrm{CF}$ application can be considered for a next level of evaluation as a promising application due to its good performance in terms of plant growth promotion in poinsettia cultivation. The bacterial formulations may be used as efficient PGPR for poinsettia production in farmer's greenhouse to reduce the need for chemical fertilizer and improve plant growth.

\section{References}

[1] Karunananda D. P. and S. E. Peiris. 2011. Evaluation of public acceptability and longevity of forced bloomed poinsettia (Euphorbia pulcherrima) pots in indoor decorations. Trop Agric Res. 23 (1): 21 - 29.

[2] Junqueira A. H. and M. Peetz. 2017. Brazilian consumption of flowers and ornamental plants: habits, practices and trends. Ornam Hortic. 23 (2): 178-184. https: //doi.org/10.14295/oh.v23i2.1070

[3] Kannangara, C. G. and M. Hansson. 1998. Arrest of chlorophyll accumulation prior to anthocyanin formation in Euphorbia pulcherrima. Plant Physiology and Biochemistry. 36 (12): 843-848.
[4] Kofranek, A. M., T. G. Byrne, R. H. Sciaroni and O. R. Lunt. 1963. Slow release fertilizers for poinsettia pot plants. California Agriculture. September. pp: 14-15.

[5] Siemonsma, R. 2007. Common poinsettia problems. Greenhouse Grower. July 2007. 8 C2009. All rights reserved. GANTEC Inc.

[6] Ecke, P. 2011. Poinsettia. Paul Ecke Poinsettias, Encintas, California. USA.

[7] Arreola, J. A., A. M. C. Gonzolez, L. A. V. Aguilar, M. T. C. Leon, J. P. Pineda and E. A. Garcia. 2008. Effect of calcium, boron and molybdenum on plant growth and bract pigmentation in poinsettia. Revista Fitotecnia Mexicana. 31 (2): 165-172.

[8] Ecke III, P., J. E. Faust, A. Higgins and J. Williams. 2004. The Ecke poinsettia manual. The Ecke poinsettia manual.

[9] Thapa, S. 2017. Production of poinsettia (Euphorbia pulcherrima) with light emitting diodes compared with the traditional high pressure sodium lamp (Master's thesis, Norwegian University of Life Sciences, Ås).

[10] Kloepper J. W., J. Leong, M. Teintze and M. N. Schroth. 1980. Enhanced plant growth by siderophores produced by plant growthpromoting rhizobacteria. Nature. 286: 885-886.

[11] Kloepper J. W., R. Lifshitz, and R. M. Zablotowicz. 1989. Free-living bacterial inocula for enhancing crop productivity. Trends in Biotechnology. 7 (Suppl 2): 39-43.

[12] Bashan, Y., L. E. de-Bashan, S. R. Prabhu and J. P. Hernandez. 2014. Advances in plant growth-promoting bacterial inoculant technology: Formulations and practical perspectives (1998-2013). (A Marschner Review). Plant Soil. 378:1-33. https: //doi.org/10.1007/s11104-013-1956-X

[13] Parewa, H. P., V. S. Meena, L. K. Jain and A. Choudhary. 2018. Sustainable crop production and soil health management through Plant Growth-Promoting Rhizobacteria. In Role of Rhizospheric Microbes in Soil (pp. 299-329). Springer, Singapore.

[14] Gunes, A., K. Karagoz, M. Turan, R. Kotan, E. Yildirim, R. Cakmakci and F. Sahin. 2015. Fertilizer efficiency of some plant growth promoting rhizobacteria for plant growth. Research journal of soil biology. 7 (2): 28-45.

[15] Gupta, G., S. S. Parihar, N. K. Ahirwar, S. K. Snehi and V. Singh. 2015. Plant growth promoting rhizobacteria (PGPR): current and future prospects for development of sustainable agriculture. J Microb Biochem Technol. 7 (2): 096-102.

[16] Hanudin, H., K. Budiarto and B. Marwoto. 2017. Application of PGPR and antagonist fungi-based biofungicide for white rust disease control and its economyc analysis in chrysanthemum production. AGRIVITA, Journal of Agricultural Science. 39 (3): 266-278.

[17] Gurung, A., Y. C. Gupta, S. Bhatia, P. Thakur and P. Yadav. 2018. Effect of integrated nutrient management on growth and production of hydrangea (Hydrangea macrophylla Thunb.). Int. J. Curr. Microbiol. App. Sci. 7 (4): 2080-2086.

[18] Utami, C. D., S. Sitawati and E. Nihayati. 2017. Aplikasi Plant Growth Promoting Rhizobacteria (PGPR) sebagai sebuah upaya pengurangan pupuk anorganik pada tanaman krisan potong (Chrysanthemum sp.). Biotropika: Journal of Tropical Biology. 5 (3): 68-72. 
[19] Zulueta-Rodriguez, R., M. V. Cordoba-Matson, L. G. Hernandez-Montiel, B. Murillo-Amador, E. Rueda-Puente and L. Lara. 2014. Effect of Pseudomonas putida on growth and anthocyanin pigment in two poinsettia (Euphorbia pulcherrima) cultivars. The Scientific World Journal Volume 2014, Article ID 810192, 6 pages.

[20] Faust J. E., P. C. KOrczynski and R. Klein. 2001. Effects of paclobutrazol drench application date on poinsettia height and flowering. HortTechnology- October-December 11 (4): 557560 .

[21] Andrade, G., K.L. Mihara, R.G. Linderman and G.J. Bethlenfalvay. 1997. Bacteria from rhizosphere and hyphosphere soils of different arbuscular-mycorrhizal fungi. Plant and soil. 192 (1): 71-79.

[22] ASA, 1982. Methods of soil analysis. Part 2. Chemical and Microbiological Properties, 2nd edition, Page A.L. (Ed.), Agronomy Society of America.

[23] Olsen, S. R. and L. E. Sommers. 1982. Phosphorus. In: Page, A.L., Miller, L.H., Keeney, D.R. (Eds.), Methods of Soil Analysis. Part 2. Chemical and microbiological properties. Agronomy Monograph, second ed., vol. 9, American Society of Agronomy, Madison, WI, pp. 403-430.

[24] Bremner, J. M. 1996. Nitrogen-Total. In: Sparks, D. L. (Ed.), Methods of soil analysis. Part 3. Chemical Methods. Soil Science Society of America Book Series Number 5. American Society of Agronomy, Madison, WI, pp. 1085-1121.

[25] Rhoades, J. D. 1982. Exchangeable Cations. Pp, 159-164. Methods of soil analysis. Part II. Chemical and microbiological properties In: (Page, A.L., R.H. Miller and D.R. Keeney eds.). 2nd Ed., ASA SSSA Publisher, Agronomy. No: 9 Madison, Wisconsin, USA.

[26] Lindsay, W. L. and W. A. Norwell. 1978. Development of DTPA soil test for zinc, 1ron, manganese and copper. Soil Sci. Soc. Amer. Proc. 33: 49-54.

[27] AOAC, (Association of Official Analytical ChemistsInternational) 2005. Official Methods of Analysis, $15^{\text {th }}$ ed. AOAC-Int., Arlington, VA.

[28] Richmond, T. R. and S. R. Radwan. 1962. A comparative study of seven methods of measuring earliness of crop maturity in cotton 1. Crop Science. 2 (5): 397-400.

[29] Bölek, Y., M. Oğlakçı and F. Kıllı. 2007. Factors determining earliness and production management in cotton (Gossypium spp.). KSU Journal of Science and Engineering. 10 (1): 116125.

[30] Rezvanypour, S., A. Hatamzadeh, S. A. Elahinia and H. R. Asghari. 2015. Exogenous polyamines improve mycorrhizal development and growth and flowering of Freesia hybrida. Journal of Horticultural Research. 23 (2): 17-25.

[31] De Silva, A., K. Patterson, C. Rothrock and J. Moore. 2000. Growth promotion of highbush blueberry by fungal and bacterial inoculants. Hortscience. 35 (7): 1228-1230.

[32] Manju, P., \& Subramanian, S. (2017). Effect of Bacillus spp. on Gerbera plant growth and control of Meloidogyne incognita. Journal of Applied and Natural Science, 9 (3), $1644-1650$

[33] Solano, B. R., M. P. De La Iglesia, A. Probanza, J. L. García, M. Megías and F. G. Manero F. G. 2007. Screening for PGPR to improve growth of Cistus ladanifer seedlings for reforestation of degraded mediterranean ecosystems. In First International Meeting on Microbial Phosphate Solubilization (pp. 59-68). Springer, Dordrecht.

[34] Rachmawati, D. and E. Korlina. 2016. Kajian penggunaan pupuk hayati untuk mengendalikan penyakit akar gada (Plasmodiophora brassicae) pada tanaman sawi daging. Agrovigor. 9 (1): 67-72.

[35] Karakurt, H. and R. Aslantaş. 2010. Effects of some plant growth promoting rhizobectaria (PGPR) strains on plant growth and leaf nutrient content of apple. Journal of Fruit and Ornamental Plant Research. 18 (1): 101-110.

[36] Yıldırım, E., M. Turan and M. F. Dönmez. 2008. Mitigation of salt stress in radish (Raphanus sativus 1.) by plant growth promoting rhizobacteria. Romanian Biotecnological letters. 13: 3933-3943.

[37] Eid, A. R., M. N. Awad and H. A. Hamouda. 2009. Evaluate effectiveness of bio and mineral fertilization on the growth parameters and marketable cut flowers of Matthiola incana $\mathrm{L}$. Am.-Eur. J. Agric. Environ. Sci. 5: 509-518.

[38] Jaleel, C. A., P. Manivannan, B. Sankar, A. Kishorekumar, R. Gopi, R. Somasundaram and R. Panneerselvam. 2007. Pseudomonas fluorescens enhances biomass yield and ajmalicine production in Catharanthus roseus under water deficit stress. Colloids and Surfaces B: Biointerfaces. 60 (1): 7-11.

[39] Martinetti, L., A. Sparacino, A. Ferrante and L. Allievi. 2007. Effect of a biofertiliser on the growth of poinsettia. In International Symposium on High Technology for Greenhouse System Management: Greensys 2007 801, 1177-1182.

[40] Won, S. J., V. Choub, J. H. Kwon, D. H. Kim and Y. S. Ahn. 2019. The Control of fusarium root rot and development of coastal pine (Pinus thunbergii Parl.) seedlings in a container nursery by use of Bacillus licheniformis MH48. Forests. 10 (1): 6 .

[41] Li, G. X., X. Q. Wu and J. R. Ye. 2013. Biosafety and colonization of Burkholderia multivorans WS-FJ9 and its growth-promoting effects on poplars. Applied microbiology and biotechnology. 97 (24): 10489-10498.

[42] Taiz, L. and E. Zeiger. 2002. Plant physiology. Sinauer Associates, Sunderland, 700.

[43] Lazarovits, G. 1995. Application of growth-promoting rhizobacteria to transplant plug and seed. HortScience. 30(4): $750-750$.

[44] Yanni, YG., R. Y. Rizk, V. Corich, A. Squartini, K. Ninke, S. Philip-Hollingsworth, G. Orgambide, F. de Bruijn, J. Stoltzfus, D. Buckley, T. M. Schmidt, P. F. Mateos, J. K. Ladha and F. B. Dazzo. 1997. Natural endophytic association between Rhizobium leguminosarum bv. trifolii and rice roots and assessment of its potential to promote rice growth. Plant Soil. 194: 99-114.

[45] Glick, B. R., C. L. Patten, G. Holguin and D. M. Penrose. 1999. Biochemical and genetic mechanisms used by plant growth promoting bacteria. Imperial College Press, London, 267.

[46] Lucy, M., E. Reed and B. R. Glick. 2004. Application of free living plant growth promoting rhizobacteria. Antonie van Leeuwenhoek. Kluwer Academic Publishers, Netherlands, 86, $1-25$. 
[47] Dobbelaere, S., J. Vanderleyden and Y. Okon. 2003. Plant growth-promoting effects of diazotrophs in the rhizosphere. Critical Reviews in Plant Sciences. 22 (2): 107-149.

[48] Çakmakçı, R. 2005. Posphate solubilizing bacteria and their role in plant growth promotion. Selcuk Journal of Agriculture and Food Sciences, 35, 93-108.

[49] Çakmakçı, R. 2005. Use of plant growth promoting rhizobacteria in agriculture. Journal of the Faculty of Agriculture, 36, 97-107.

[50] Saharan, B. S. and V. Nehra. 2011. Plant growth promoting rhizobacteria: a critical review. Life Sciences and Medicine Research. 21: 1-30.

[51] Mia, M. A. B., Z. H. Shamsuddin, Z. Wahab and M. Marziah. 2005. High-yielding and quality banana production through plant growth-promoting rhizobacterial (PGPR) inoculation. Fruits. 60 (3): 179-185.

[52] Mena-Violante, H. G. and V. Olalde-Portugal. 2007. Alteration of tomato fruit quality by root inoculation with plant growth-promoting rhizobacteria (PGPR): Bacillus subtilis BEB-13bs. Scientia Horticulturae. 113 (1): 103-106.

[53] Pérez García, M., M. A. De la Rosa Ibarra, J. Maldonado, A. Coasesor, M. Amador and S. Y. Coasesor. 2017. Evaluación del efecto de dos microorganismos en la colonización de la raíz y promoción del crecimiento y desarrollo de plántulas de maíz (Zea mays L.).

[54] Díaz, V. P., R. Ferrera-Cerrato, J. J. Almaraz-Suárez and G. Alcántary. 2001. Inoculación de bacterias promotoras de crecimiento en lechuga. Terra. 19 (4): 327-335.

[55] Aguirre-Cadena, J. F., S. Reyna, M. Cautle and J. F. AguirreMedina. 2014. Sobrevivencia de Azospirillum brasilense después de aplicar herbicidas en Triticum aestivum L. Var. Altiplano. Revista Mexicana de Ciencias Agrícolas. 5 (8): 1549-1555.

[56] Soyergin, S., 2003. Protection of soil efficiency in organic agriculture, fertilizers and organic soil improvers. Atatürk Horticulture Central Research Institute, Yalova

[57] Prasad, R. 2005. Organic farming vis-à-vis modern agriculture. Current science. 89 (2): 252-254.

[58] Cakmakçi, R., F. Dönmez, A. Aydın and F. Şahin. 2006. Growth promotion of plants by plant growth-promoting rhizobacteria under greenhouse and two different field soil conditions. Soil Biology and Biochemistry. 38: 1482-1487.

[59] Chen, J. H. 2006. The combined use of chemical and organic fertilizers and/or biofertilizer for crop growth and soil fertility. In International workshop on sustained management of the soil-rhizosphere system for efficient crop production and fertilizer use. 16, 20. Land Development Department Bangkok, Thailand.

[60] Patten, C. L. and B. R. Glick. 2000. Isolation and characterization of indole acetic acid biosynthesis genes from plant growth promoting bacteria. In Fifth International PGPR Workshop (Vol. 29).

[61] Sahin F., R. Cakmakci and F. Kantar. 2004. Sugar beet and barley yields in relation to inoculation with N2 -fixing and phosphate solubilizing bacteria. Plant Soil. 265:123-129.

[62] Altın, N. and B. O. R. A. Tayyar. 2005. Common properties and effects of plant growth promoting rhizobacteria. Anadolu, J. of AARI. 15 (2): 87 - 103.

[63] Orhan, E., A. Eşitken, S. Ercişli, M. Turan and F. Şahin. 2006. Effects of plant growth promoting rhizobacteria (PGPR) on yield growth and nutrient contents in organically growing raspberry. Scientia Horticulturae. 111: 38-43.

[64] Singh, Y. P. and C. P. S. Chauhan. 2005. Effect of sulphur, phosphorus and Rhizobium inoculation on yield, content of micronutrients and phosphorus utilization of lentil. Indian Journal of Pulses Research. 18 (2): 211.

[65] Antoun, H., C. J. Beauchamp, N. Goussard, R. Chabot and R. Lalande. 1998. Potential of Rhizobium and Bradyrhizobium species as plant growth promoting rhizobacteria on nonlegumes: effect on radishes (Raphanus sativus L.). In Molecular microbial ecology of the soil (pp. 57-67). Springer, Dordrecht.

[66] Bhattacharyya, P. N. and D. K. Jha. 2012. Plant growthpromoting rhizobacteria (PGPR): emergence in agriculture. World Journal of Microbiology and Biotechnology. 28 (4): 1327-1350.

[67] Das, I. And A. P. Singh. 2014. Effect of PGPR and organic manures on soil properties of organically cultivated mungbean. Bioscan. 9 (1): 27-29.

[68] Singh, C. S. and N. S. Subba Rao. 1979. Associative effect of Azospirillum brasilense with Rhizobium japonicum on nodulation and yield of soybean (Glycine max). Plant Soil. 53: 387-392

[69] Prasad, H. and R. Chandra. 2003. Growth pattern of urdbean Rhizobium sp. with PSB and PGPR in consortia. Journal of the Indian Society of Soil Science. 51 (1): 76-78.

[70] Gunasekaran, S., D. Balachandar and K. M. Sundaram. 2004. Studies on synergism between Rhizobium, plant growth promoting rhizobacteria (PGPR) and phosphate solubilizing bacteria in blackgram. Biofertilizers technology. 269-272.

[71] Arab, A., G. R. Zamani, M. H. Sayyari and J. Asili. 2015. Effects of chemical and biological fertilizers on morphophysiological traits of marigold (Calendula officinalis L.). European Journal of Medicinal Plants. 8 (1): 60, 68.

[72] Verma, S. C., J. K. Ladha and A. K. Tripathi. 2001. Evaluation of plant growth promoting and colonization ability of endophytic diazotrophs from deep water rice. Journal of Biotechnology. 91 (2-3): 127-141.

[73] Malinovskaya I. M., L. V. Kosenko, S. K. Votselko and V. S. Podgorskii. 1990 Role of Bacillus mucilaginosus polysaccharide in degradation of silicate minerals. Mikrobiol. 59: 49-55.

[74] Barker W. W., S. A. Welch, S. Chu and F. Banfield. 1998. Experimental observations of the effects of bacteria on aluminosilicate weathering. Am Mineral. 83: 1551-1563.

[75] Sheng X. F. and W. Y. Huang. 2002. Mechanism of potassium release from feldspar affected by the strain NBT of silicate bacterium. Acta Pedologica Sinica. 39:863-871.

[76] Martínez, M. F. 1995. Manual práctico de nochebuena. Consultoría OASIS. Morelos, México. 87 p.

[77] Dole J. M. and H. F. Wilkins. 2005. Floriculture principles and species. Prentice Hall, Upper Saddle River, N. J. 
[78] McAvoy, R. and B. Bible. 2000. Relationship of bract boron content and bo-ron application to bracts necrosis of poinsettia. HortScience. 35:457.

[79] Glick, B. R. 1995. The enhancement of plant growth by freeliving bacteria. Can J Microbiol. 41: 109-117.

[80] Shen L., S. Liu, L. Lou, W. Liu, X. Xu, P. Zheng and B. L. Hu. 2013. Broad distribution of diverse anaerobic ammoniumoxidizing bacteria in Chinese agricultural soils. Appl Environ Microbiol. 79: 6167-6172.

[81] Bakırcığlu, D., 2009. Determination of macro and micro elements in soil. PhD Dissertation. Trakya University,
Graduate School of Sciences, Chemistry Program, Edirne.

[82] Balashouri, P., 1995. Effect of zinc on germination, growth and pigment content and phytomass of Vigna radiata and Sorghum bicolour. Journal of Ecobiology. 7: 109-114.

[83] Kotan R., A. Çakir, H. Ozer, Ş. Kordali, R. Çakmakci, F. Dadasoglu, N. Dikbaş, T. Aydin and C. Kazaz. 2014. Antibacterial effects of Origanum onites against phytopathogenicbacteria: Possible use of the extracts from protection of diseasecaused by some phytopathogenic bacteria. Scientia Horticulturae. 172: 210-220. https: //doi.org/10.1016/j.scienta.2014.03.016. 